\section{Injury to Landscape and Vegetable Plants by Volatile Turf Herbicides}

\author{
Philip Busey, ${ }^{1}$ \\ Timothy K. Broschat, ${ }^{2}$ and \\ Diane L. Johnston ${ }^{3}$
}

Additional index words. 2,4-D, ester, phenoxy herbicide, volatility, Alternanthera ficoidea, Lycopersicon esculentum, Tagetes evecta

\begin{abstract}
Summary. Phenoxy and related herbicides used in turfgrass have the potential for volatilization and movement from treated areas. Three studies assessed potential injury to subtropical landscape plants caused by volatile turf herbicides in polyethylene enclosures. Phenoxy herbicide mixtures were emphasized. There were significant differences among the seven landscape species tested. The most sensitive species were african marigold (Tagetes evecta), joseph's coat (Alternanthera ficoidea), and tomato (Lycopersicon esculentum). Severe injury was caused by exposure to herbicides containing 2,4-D isooctyl ester and MCPA isooctyl ester. Exposure to individual active ingredients 2,4-D dimethylamine, dicamba acid, atrazine, and metsulfuron resulted in no injury to the species tested.
\end{abstract}

$\mathrm{F}$ oliar applications of phenoxy herbicides such as 2,4-D control broadleaf weeds in turfgrass (Marth and Mitchell, 1944). Other phenoxy herbicides such as mecoprop, and dicamba (a benzoic acid herbicide), are mixed with 2,4-D to synergistically increase control of weeds in turfgrass (Bowen and Morris, 1969). A wide array of mixtures is marketed commercially.

Fort Lauderdale Research and Education Center, University of Florida, 3205 College Ave., Fort Lauderdale, FL 33314.

This research was supported in part by the Florida Agricultural Experiment Station and approved for publication as journal series R-09246. We thank Susan Thor for technical assistance, and PBI/Gordon Corporation for partial support of the research.

${ }^{1}$ Associate professor of environmental horticulture; corresponding author; e-mail turf@ufl.edu.

${ }^{2}$ Professor of environmental horticulture.

${ }^{3}$ Biological scientist
Phenoxy and related herbicides can injure nontarget susceptible plants, due in part to their auxin effect, even at low exposure dosages. Injurious amounts of herbicide can reach nontarget plants by some combination of spray drift and herbicide volatilization, depending on chemical characteristics and application conditions such as wind, relative humidity, drying time, and sorption. Despite extensive use of phenoxy and related herbicide mixtures in turf, there is little scientific documentation on the effect of turf applications on nearby nontarget landscape plants.

While water-soluble amine salts of 2,4-D have low volatility, oil-soluble ester formulations sometimes have high volatility. Following application of a granular formulation of 2,4-D isooctyl ester (=2-ethylhexyl ester) to kentucky bluegrass (Poa pratensis) turf in chambers, air concentration of $2,4-\mathrm{D}$ is in the $\mathrm{ng} \cdot \mathrm{m}^{-3}\left(10^{-12} \mathrm{oz} / \mathrm{ft}^{3}\right)$ range (Nash and Beall, 1980). Vapor pressure of a chemical determines the saturated gaseous concentration of the chemical in the atmosphere, and hence, its volatility. Volatile injury to tomato (Lycopersicon esculentum) occurs from 2,4 -D formulations having vapor pressures of 0.6 to $3.3 \mathrm{mPa}$ at $25^{\circ} \mathrm{C}(8.70$ $\times 10^{-8}$ to $4.79 \times 10^{-7} \mathrm{lb} /$ inch $^{2}$ at 77.0 $\left.{ }^{\circ} \mathrm{F}\right)$ (Noble and Hamilton, 1990). Formulations with vapor pressures below $0.6 \mathrm{mPa}$ are low volatility and above $3.3 \mathrm{mPa}$ they are highly volatile. Small additions of other molecular forms of herbicides can greatly affect volatility. For example, addition of $1.1 \mathrm{~g} \cdot \mathrm{L}^{-1}$ $(0.15 \mathrm{oz} / \mathrm{gal}) 2,4-\mathrm{D}$ methyl ester can change 2,4-D isooctyl ester from low volatile to high volatile (Noble and Hamilton, 1990).

The vapor pressure of $2,4-\mathrm{D}$ and other herbicides increases 3 - to 4 -fold with each $10{ }^{\circ} \mathrm{C}\left(18.0^{\circ} \mathrm{F}\right)$ increase in temperature (Branham, 1994). For each $10{ }^{\circ} \mathrm{C}$ increase in temperature, dissipation and volatilization increase 1.4 times and 1.8 times, respectively, and volatilization fluxes of acid herbicides such as 2,4-D from treated soil are as high as $132 \mathrm{~g} \cdot \mathrm{ha}^{-1}(1.9 \mathrm{oz} /$ acre $)$ per day at $35^{\circ} \mathrm{C}\left(95.0^{\circ} \mathrm{F}\right)$ (Nash, 1989). Daytime temperatures can exceed 30 ${ }^{\circ} \mathrm{C}\left(86.0^{\circ} \mathrm{F}\right)$ throughout the year in southern Florida, which increases the potential for nontarget injury to other landscape plants due to volatilization and movement of herbicide from treated turfgrass areas.
Vapors from corn (Zea mays) treated with dicamba dimethylamine injure soybean (Glycine max) plants 60 $\mathrm{m}(196.9 \mathrm{ft})$ downwind (Behrens and Lueschen, 1979). Buffer zones of 5 to $10 \mathrm{~m}$ (16.4 to $32.8 \mathrm{ft}$ ) are suggested for ground sprayers to minimize the risk of injury to native plants from MCPA, another phenoxy herbicide (Marrs et al., 1989). Sentinel plants such as tomato and lettuce (Lactuca sativa) have been used to detect nontarget drift of phenoxy herbicides (van Rensburg and Breeze, 1990; Welker and Peterson, 1989). Annual bedding plants are sensitive to low rates of spray drift of 2,4-D and triclopyr, with petunia (Petunia $\times$ bybrida) the most sensitive among nine species tested (HattermanValenti et al., 1995).

The objective of these studies was to assess potential injury to subtropical landscape plants caused by volatile turf herbicides, emphasizing phenoxy herbicide mixtures. Atrazine and metsulfuron were also included as alternative broadleaf herbicides used in subtropical turf.

\section{Materials and methods}

Herbicide injury was assessed using clear polyethylene plastic enclosures. Representative subtropical landscape plants were exposed, for 24 $h$, to vapors from herbicide formulations inside the enclosures. Enclosures were $114 \times 114 \times 97 \mathrm{~cm}$ high $(44.9 \times 44.9$ $\times 38.2$ inches high). They were placed outdoors under a nearly opaque fiberglass roof for protection from sun and rain. In Study 1, the landscape plants were african marigold, cape honeysuckle (Tecomaria capensis), evolvulus (Evolvulusglomeratus) ‘Blue Daze,' joseph's coat, mexican heather (Cuphea hyssopifolia), periwinkle (Catharanthusroseus), and tomato. In Study 2 and Study 3, only african marigold (Tagetes erecta), joseph's coat, and tomato were used.

In each of the three studies, six or seven herbicide treatments were compared, along with a water control treatment (Table 1). Each study was a randomized complete block design with four replicates (blocks). Each replicate was set up and treated on a different day. Each enclosure within a daily replicate contained a complete set of plant species. The main-plot experimental unit was thus a set of plants exposed simultaneously in one enclosure, and plant species were split plots. Study 1 had one plant of each 
species per enclosure. Study 2 and Study 3 had two plants of each species (subsamples) per enclosure.

Formulated herbicides were mixed with water to bring them to $24.4 \mathrm{~mL}(0.83 \mathrm{fl} \mathrm{oz})$ and the mixtures were poured onto a layer of paper towel placed to cover the bottom of a 30.0 $\times 20.5 \times 5.1-\mathrm{cm}$-deep $(11.81 \times 8.07$ $\times 2.01$ inches) aluminum pan in each enclosure. The poured volume, 24.4 $\mathrm{mL}$, would equal a spray application rate of $18.7 \mathrm{~mL} \cdot \mathrm{m}^{-2}(20 \mathrm{gal} / \mathrm{acre})$, if it had been sprayed onto the basal area of the enclosure. Movement of volatilized herbicide from the soaked paper towel was facilitated using a D-cell batterypowered fan, and enclosures remained closed for $24 \mathrm{~h}$. Temperatures inside enclosures were between 23 and $40{ }^{\circ} \mathrm{C}$ (73.4 and $104.0^{\circ} \mathrm{F}$ ) during herbicide exposure.

Plant injury was rated based on a visual estimate of overall severity. Injury factors considered were bending of stem and petioles, downward curling of leaf margins resulting in leaf cupping, swelling of stems associated with callus, proliferation of roots from the aboveground stems, discoloration of leaves or stems, and flower drop. The injury rating scale was 0 to 100 . The criteria for the different ratings were $0=$ no symptoms; $10=$ slight, $10^{\circ}$ bending of stems or petioles, or slight bronzing of leaves; $30=$ curling of leaf margins and/or $30^{\circ}$ bending of stems and/or noticeable root proliferation at base of stems; $60=90$ to $180^{\circ}$ bending of stems and/or callus swelling of stems and/or stems proliferating roots up to the first branch and/or minimal necrosis; 80 = severe necrosis; and 100 $=$ plant dead. In Study l, plant injury was evaluated $1,3,7,14,21$, and 28 $\mathrm{d}$ after herbicide exposure. In Study 2 and Study 3 , plant injury was evaluated 1 through $9 \mathrm{~d}$ after herbicide exposure. To simplify tabular presentation, l-week data (Table 1) represented the 7-d injury rating from Study 1, or the average of 6- through 9-d injury ratings from Study 2 and Study 3. Data were analyzed by analysis of variance considering replicate effects, herbicide treatment effects, species effects, and herbicide $\mathrm{x}$ species interaction, with the appropriate error mean square used as the test statistic for the split-plot design. The main-plot effect of herbicide treatment means was separated by the Waller-Duncan $\mathrm{k}$ ratio $t$ test, $\mathrm{k}=100$ $(P \approx 0.05)$.

\section{Results}

STUdy 1. Except for Trimec Classic (PBI/Gordon Corp., Kansas City, Mo.), exposure to all herbicides injured $(P<0.0001)$ all landscape plants within $1 \mathrm{~d}$ after treatment (data not presented). The injurious herbicides all contained an ester, either 2,4-D isooctyl ester or MCPA isooctyl ester. The earliest injury symptom was epinasty, or bending of terminal stems and leaf petioles, which was noticed in all species except mexican heather and periwinkle. In periwinkle there was only curling of leaf margins and petals. Joseph's coat showed the most injury within $3 \mathrm{~d}$ after exposure. By $7 \mathrm{~d}$ after exposure, stems in tomato and cape honeysuckle began to thicken with callus, while in african marigold there were roots initiated along the stem.

Herbicides differed strongly in plant injury $7 \mathrm{~d}$ after exposure. Herbicide $\times$ species interaction was highly significant $(P<0.0001)$. African marigold was most injured by Cool Power (Riverdale Chemical Co., Burr Ridge, Ill.), joseph's coat was most injured by Super Trimec (PBI/Gordon Corp.), and tomato was most injured by SpeedZone (PBI/Gordon Corp.) (Table 1). Injury was only slightly worse at $14 \mathrm{~d}$ than at $7 \mathrm{~d}$. In Study 1, few african marigold and periwinkle plants survived after $7 \mathrm{~d}$ after treatment, due both to herbicide treatment and possibly other factors. Other species, cape honeysuckle and mexican heather, appeared to be capable of recovering from herbicide injury, as the main symptom was flower damage.

STUdy 2. Exposure to 2,4-D isooctyl ester alone, and to Super Trimec, injured african marigold, joseph's coat, and tomato. Mecoprop potassium salt injured tomato and african marigold but not joseph's coat (Table 1). Dicamba dimethylamine caused slight injury only to joseph's coat. Dicamba acid, mecoprop dimethylamine, and 2,4-D dimethylamine caused no injury.

STUdy 3. Exposure to Super Trimec and SpeedZone St. Augustine, both containing 2,4-D isooctyl ester, injured african marigold, joseph's coat, and tomato. Moderate injury was caused only to african marigold and tomato by Ortho Weed-B-Gon Lawn Weed Killer (Solaris Group of Monsanto Co., San Ramon, Calif.), Trimec Southern (PBI/Gordon Corp.), and Trimec Classic. All three herbicide products contained 2,4-D dimethyl- amine + mecoprop dimethylamine + dicamba dimethylamine. There was no difference in injury among these three products, even though the rate of application, on the basis of the basal area of the enclosures, ranged from a 2,4-D acid equivalent of $0.21 \mathrm{~kg} \cdot \mathrm{ha}^{-1}(0.187$ $\mathrm{lb} /$ acre $)$ to $1.14 \mathrm{~kg} \cdot \mathrm{ha}^{-1}(1.017 \mathrm{lb} /$ acre). Other turf herbicides, atrazine and metsulfuron, caused no injury.

\section{Discussion}

Landscape plants showed no injury when exposed to 2,4-D dimethylamine alone applied in an enclosure at acid equivalent of $0.56 \mathrm{~kg} \cdot \mathrm{ha}^{-1}(0.500$ $\mathrm{lb} / \mathrm{acre})$. In contrast, landscape plants were consistently and severely injured when exposed to herbicides containing 2,4-D isooctyl ester as low as acid equivalent $0.29 \mathrm{~kg} \cdot \mathrm{ha}^{-1}(0.259 \mathrm{lb} /$ acre). The injurious products were 2,4-D isooctyl ester by itself, along with mixtures Super Trimec, SpeedZone, and SpeedZone St. Augustine.

Severe injury was observed when landscape plants were exposed to volatile herbicides containing MCPA isooctyl ester, e.g., Cool Power and Power Zone. Both products also contained dicamba acid and either triclopyr or mecoprop acid. Because dicamba acid by itself caused no injury, the simplest explanation for the severe injury caused by Cool Power and Power Zone is that it was caused by MCPA isooctyl ester.

Three different mixtures containing 2,4-D dimethylamine + mecoprop dimethylamine + dicamba dimethylamine (Trimec Classic, Weed-B-Gon, and Trimec Southern) caused slight ( $P$ $<0.05$ ) injury to african marigold and tomato in Study 3, but not joseph's coat, at 2,4-D acid equivalent as high as $1.14 \mathrm{~kg} \cdot \mathrm{ha}^{-1}$. Because neither 2,4-D dimethylamine, nor mecoprop dimethylamine, nor dicamba dimethylamine alone injured african marigold or tomato in Study 2, the data suggest that the mixtures were injurious because of an interaction among ingredients in Study 3.

The enclosure method allowed the controlled assessment of landscape plant injury due to volatilization of turf herbicides, and was capable of providing a comparison of complex herbicide mixtures. Specific injury levels may not represent what would occur in the field. The method of herbicide application, pouring a liquid into a small tray, probably extended drying time and 
Table 1. Application rate of formulated herbicide products and active ingredients, and injury to tomato, african marigold, and joseph's coat, $7 \mathrm{~d}$ after exposure (Study 1) or 5 to $9 \mathrm{~d}$ after exposure (Studies 2 and 3). Data are means of four replications.

\begin{tabular}{|c|c|c|c|c|c|c|c|c|c|c|}
\hline \multirow[b]{2}{*}{$\begin{array}{l}\text { Herbicide } \\
\text { product }^{\mathrm{x}}\end{array}$} & \multirow{2}{*}{$\begin{array}{l}\text { ormulated } \\
\text { herbicide } \\
\text { product } \\
\text { rate } \\
\left(\mathrm{L} \cdot \mathrm{ha}^{-1}\right)^{\mathrm{w}}\end{array}$} & \multicolumn{8}{|c|}{$\begin{array}{l}\text { Active ingredient application rate } \\
\text { as acid equivalents }\left(\mathrm{kg} \cdot \mathrm{ha}^{-1}\right)^{\mathrm{z}}\end{array}$} & \multirow[b]{2}{*}{$\begin{array}{l}\text { Other active } \\
\text { ingredients } \\
\left(\text { a.i. } \mathrm{kg} \cdot \mathrm{ha}^{-1}\right)\end{array}$} \\
\hline & & $\begin{array}{c}2,4-\mathrm{D} \\
\text { isooctyl } \\
\text { ester }\end{array}$ & $\begin{array}{r}2,4-\mathrm{D} \\
\mathrm{dma}^{\mathrm{v}}\end{array}$ & $\begin{array}{c}\text { MCPA } \\
\text { isooctyl } \\
\text { ester }\end{array}$ & $\begin{array}{c}\text { Mecoprop } \\
\text { potassium } \\
\text { salt }\end{array}$ & $\begin{array}{c}\text { Mecoprop } \\
\text { dma }\end{array}$ & $\begin{array}{c}\text { Mecoprop } \\
\text { acid }\end{array}$ & $\begin{array}{c}\text { Dicamba } \\
\text { acid }\end{array}$ & $\begin{array}{c}\text { Dicamba } \\
\text { dma }\end{array}$ & \\
\hline \multicolumn{11}{|l|}{ Study 1} \\
\hline Super Trimec & 3.5 & 0.85 & 0 & 0 & 0 & 0 & 0 & 0.21 & 0 & 2,4-DP (0.86) \\
\hline Cool Power & 4.1 & 0 & 0 & 1.47 & 0 & 0 & 0 & 0.15 & 0 & Triclopyr (0.15) \\
\hline SpeedZone & 5.9 & 1.07 & 0 & 0 & 0 & 0 & 0.34 & 0.10 & 0 & Carfentrazone (0.04) \\
\hline SpeedZone St. A. & 6.5 & 0.40 & 0 & 0 & 0 & 0 & 0.16 & 0.04 & 0 & Carfentrazone (0.03) \\
\hline Power Zone & 4.7 & 0 & 0 & 1.24 & 0 & 0 & 0.25 & 0.12 & 0 & Carfentrazone (0.02) \\
\hline Trimec Classic & 4.7 & 0 & 1.14 & 0 & 0 & 0.61 & 0 & 0 & 0.12 & --- \\
\hline Water & --- & 0 & 0 & 0 & 0 & 0 & 0 & 0 & 0 & --- \\
\hline \multicolumn{11}{|l|}{ Study 2} \\
\hline Super Trimec & 3.5 & 0.85 & 0 & 0 & 0 & 0 & 0 & 0.21 & 0 & 2,4-DP (0.86) \\
\hline 2,4 -D isooctyl ester & er 1.2 & 0.56 & 0 & 0 & 0 & 0 & 0 & 0 & 0 & --- \\
\hline Mecoprop K salt & 1.2 & 0 & 0 & 0 & 0.56 & 0 & 0 & 0 & 0 & --- \\
\hline Dicamba dma & 1.2 & 0 & 0 & 0 & 0 & 0 & 0 & 0 & 0.56 & --- \\
\hline 2,4-D dma & 1.2 & 0 & 0.56 & 0 & 0 & 0 & 0 & 0 & 0 & --- \\
\hline Dicamba acid & 1.2 & 0 & 0 & 0 & 0 & 0 & 0 & 0.56 & 0 & --- \\
\hline Mecoprop dma & 1.2 & 0 & 0 & 0 & 0 & 0.56 & 0 & 0 & 0 & --- \\
\hline Water & --- & 0 & - & 0 & 0 & 0 & 0 & 0 & 0 & --- \\
\hline \multicolumn{11}{|l|}{ Study 3} \\
\hline Super Trimec & 3.5 & 0.85 & 0 & 0 & 0 & 0 & 0 & 0.21 & 0 & 2,4-DP (0.86) \\
\hline SpeedZone St. A. & 4.7 & 0.29 & 0 & 0 & 0 & 0 & 0.11 & 0.03 & 0 & Carfentrazone (0.02) \\
\hline Weed-B-Gon & 8.0 & 0 & 0.21 & 0 & 0 & 0.72 & 0 & 0 & 0.09 & --- \\
\hline Trimec Classic & 4.7 & 0 & 1.14 & 0 & 0 & 0.61 & 0 & 0 & 0.12 & --- \\
\hline Trimec Southern & 2.3 & 0 & 0.42 & 0 & 0 & 0.78 & 0 & 0 & 0.09 & --- \\
\hline Atrazine & 4.7 & 0 & 0 & 0 & 0 & 0 & 0 & 0 & 0 & Atrazine (2.24) \\
\hline Metsulfuron & (dry) & 0 & 0 & 0 & 0 & 0 & 0 & 0 & 0 & Metsulfuron (0.04) \\
\hline Water & --- & 0 & 0 & 0 & 0 & 0 & 0 & 0 & 0 & --- \\
\hline
\end{tabular}

${ }^{\mathrm{z}} 1.00 \mathrm{~kg} \cdot \mathrm{ha}^{-1}=0.892 \mathrm{lb} /$ acre. Active (or acid) ingredient application rate is calculated on the basis of active amount poured in a pan divided by the basal area of the enclosure. yithin a study, means in columns with a letter in common are not different by the Waller-Duncan $\mathrm{k}$ ratio $t$ test at $\mathrm{k}=100(P \approx 0.05)$.

${ }^{x}$ Sources and trade names: Atrazine from Atrazine 4L (Sipcam Agro USA, Inc., Roswell, Ga.); Cool Power (Riverdale Chemical Company, Burr Ridge, Ill.) ; 2,4-D diethylamine from Amine 400 (PBI/Gordon Corporation, Kansas City, MO); mecoprop K salt from Mecomec 4 (PBI/Gordon Corporation);

metsulfuron from Manor (Riverdale Chemical Company); Power Zone (PBI/Gordon Corporation); SpeedZone (PBI/Gordon Corporation); SpeedZone St. A.

(SpeedZone St. Augustine Formula, PBI/Gordon Corporation); Super Trimec (PBI/Gordon Corporation); Trimec Classic (PBI/Gordon Corporation); Trimec Southern (PBI/Gordon Corporation); Weed-B-Gon (Ortho Weed-B-Gon Lawn Weed Killer, Solaris Group of Monsanto Co., San Ramon, Calif.).

${ }^{\mathrm{w}} \mathrm{L} \cdot \mathrm{ha}{ }^{-1}=0.107 \mathrm{gal} / \mathrm{acre}$.

${ }^{\mathrm{v}} \mathrm{dma}=$ dimethylamine.

the duration of exposure to herbicide vapor. The enclosures prevented movement of volatile herbicides to the atmosphere and confined herbicide vapors near the plants for a longer time. However, the lack of direct sunlight may have affected leaf surface temperature, compared with field application, and affected volatilization. Further research should consider using controlled miniature landscapes exposed to the atmosphere and sunlight. In an enclosed environment, volatile phenoxy herbicides containing 2,4-D isooctyl ester as well as MCPA isooctyl ester can severely injure landscape species.

\section{Literature cited}

Behrens, R. and W.E. Lueschen. 1979. Dicamba volatility. Weed Sci. 27:486-493.

Bowen, P. and R.L. Morris. 1969. Broadleaf weed control in turf: Mixtures of dicamba with 2,4-D and MCPA. Proc. First Intl. Turfgrass Res. Conf. 1:380-392.

Branham, B.E. 1994. Herbicide fate in turf, p. 109-151 In: A.J. Turgeon (ed.). Turf weeds and their control. American Society of Agronomy, Madison, Wis.

Hatterman-Valenti, H., N.E. Christians, and M.D.K. Owen. 1995. Effect of 2,4-D and triclopyr on annual bedding plants. J. Environ. Hort. 13:122-125.

Marrs, R.H., C.T. Williams, A.J. Frost, and R.A. Plant. 1989. Assessment of the effects of herbicide spray drift on a range of plant species of conservation interest. Environ. Pollution 59:71-86.

Marth, P.C. and J.W. Mitchell. 1944. 2,4- dichlorophenoxy acetic acid as a differential herbicide. Bot. Gaz. 106:224-232.

Nash, R.G. 1989. Volatilization and dissipation of acidic herbicides from soil under controlled conditions. Chemosphere 18: 2363-2374.

Nash, R.G. and M.L. Beall, Jr. 1980. Distribution of silvex, 2,4-D, and TCDD applied to turf in chambers and field plots. J. Agr. Food Chem. 28:614-623.

Noble, A. and D.J. Hamilton. 1990. Relation between volatility rating and composition of phenoxy herbicide ester formulations. Pesticide Sci. 28:203-214.

van Rensburg, E. and V.G. Breeze. 1990. Vapor effects of 2,4-D derivatives on seed germination of two field-crops. Seed Sci. Technol. 18:577-580.

Welker, Jr., W.V. and D.L. Peterson. 1989. A surface-roller herbicide applicator for weed control in turf. Weed Technol. 3: 472-474. 


\title{
Soil Depth and Tillage Effects on Dry Bean Production
}

\begin{tabular}{ccc}
\multicolumn{3}{c}{ Injury $(\%)^{\mathrm{y}}$} \\
$\begin{array}{c}\text { Joseph's } \\
\text { coat }\end{array}$ & Marigold & Tomato \\
\hline & & \\
$68 \mathrm{a}$ & $58 \mathrm{ab}$ & $48 \mathrm{a}$ \\
$53 \mathrm{~b}$ & $65 \mathrm{a}$ & $43 \mathrm{ab}$ \\
$53 \mathrm{~b}$ & $35 \mathrm{~b}$ & $50 \mathrm{a}$ \\
$50 \mathrm{~b}$ & $35 \mathrm{~b}$ & $48 \mathrm{a}$ \\
$50 \mathrm{~b}$ & $38 \mathrm{~b}$ & $38 \mathrm{~b}$ \\
$0 \mathrm{c}$ & $0 \mathrm{c}$ & $0 \mathrm{c}$ \\
$0 \mathrm{c}$ & $0 \mathrm{c}$ & $0 \mathrm{c}$ \\
& & \\
$68 \mathrm{a}$ & $83 \mathrm{a}$ & $83 \mathrm{a}$ \\
$47 \mathrm{~b}$ & $67 \mathrm{~b}$ & $71 \mathrm{~b}$ \\
$0 \mathrm{~d}$ & $35 \mathrm{c}$ & $57 \mathrm{c}$ \\
$15 \mathrm{c}$ & $0 \mathrm{~d}$ & $0 \mathrm{~d}$ \\
$0 \mathrm{~d}$ & $1 \mathrm{~d}$ & $3 \mathrm{~d}$ \\
$0 \mathrm{~d}$ & $1 \mathrm{~d}$ & $2 \mathrm{~d}$ \\
$0 \mathrm{~d}$ & $1 \mathrm{~d}$ & $1 \mathrm{~d}$ \\
$0 \mathrm{~d}$ & $0 \mathrm{~d}$ & $0 \mathrm{~d}$ \\
$69 \mathrm{a}$ & & \\
$29 \mathrm{~b}$ & $68 \mathrm{a}$ & $72 \mathrm{a}$ \\
$2 \mathrm{c}$ & $47 \mathrm{~b}$ & $44 \mathrm{~b}$ \\
$5 \mathrm{c}$ & $27 \mathrm{c}$ & $21 \mathrm{c}$ \\
$1 \mathrm{c}$ & $19 \mathrm{c}$ & $17 \mathrm{c}$ \\
$0 \mathrm{c}$ & $20 \mathrm{c}$ & $19 \mathrm{c}$ \\
$0 \mathrm{c}$ & $0 \mathrm{~d}$ & $0 \mathrm{~d}$ \\
$0 \mathrm{c}$ & $0 \mathrm{~d}$ & $0 \mathrm{~d}$ \\
& $0 \mathrm{~d}$ & $0 \mathrm{~d}$ \\
\hline
\end{tabular}

\author{
V.M. Russo
}

Additional index words. Phaseolus vulgaris, black bean, culture, pinto bean

Summary. The effects of soil depth on yields of dry bean (Phaseolus vulgar$i s)$ produced under different types of tillage is not well understood. Black and pinto bean yields were evaluated under conventional and reducedtillage for 2 years in a 3.24-ha (8-acre) commercial field in southeastern Oklahoma. Before planting, a grid pattern was laid out on the field with points at every $13.7 \mathrm{~m}(45.0 \mathrm{ft})$ north to south and $6.1 \mathrm{~m}(20.0 \mathrm{ft})$ east to west. Samples were taken at each intersection of the grid lines (496 sites) to determine $\mathrm{pH}$, and the amounts of nitrogen, phosphorus, and potassium present in soil. Depth to an impervious clay pan was determined at these sites, and were grouped as being one of the following: <25 $\mathrm{cm}$ (9.8 inches), $>25$ to $50 \mathrm{~cm}$ (19.7 inches), $>50$ to $75 \mathrm{~cm}$ (29.5 inches) and $>75 \mathrm{~cm}$. Irrigation was supplied, if needed, at $\mathbf{5 0 \%}$ flowering and, in both years, at $50 \%$ pod set. There was no significant effect on yield due to year. Black bean yields from conventional tillage averaged $1166 \mathrm{~kg} \cdot \mathrm{ha}^{-1}$ (1040.4 lb/acre) across soil depths and were better than yields from reduced-tillage which averaged $136 \mathrm{~kg} \cdot \mathrm{ha}^{-1}(121.3 \mathrm{lb} / \mathrm{acre})$. Pinto bean yields from conventional tillage were $611 \mathrm{~kg} \cdot \mathrm{ha}^{-1}(545.2 \mathrm{lb} / \mathrm{acre})$ across soil depths and were better than for reduced tillage, which averaged 403 $\mathrm{kg} \cdot \mathrm{ha}^{-1}(359.6 \mathrm{lb} / \mathrm{acre})$. Yields generally were reduced as soil depth increased regardless of tillage type. The reduction in input for reduced-tillage would not compensate for the reduced yields for plants grown on the most productive soil depths.

$\mathrm{D}$ ry beans, components of a balanced diet (Quebedeaux and Bliss, 1988), are grown wherever environmental conditions will allow (Gepts, 1998). World wide, beans are an important source of protein in diets, especially in developing countries (Pachico, 1989). In addition, black beans, and to a lesser extent pinto beans, contain phytoestrogens that may be important to women's health (Franke et al., 1994).

There is increased interest in the Southern Plains of the United States in alternative crops to be used to diversify current types of agriculture. Dry beans are under study for production in the region. Previous studies at Lane, Okla. indicated that there is a wide range of yields for beans, which is likely due to environmental conditions occurring during production (Russo, 1995;

United States Department of Agriculture, Agricultural Research Service, South Central, Agricultural Research Laboratory, P.O. Box 159, Hwy. 3W, Lane, OK 74555; email vrusso-usda@lane-ag.org.

Mention of a trademark, vendor, or proprietary product, or vendor does not constitute a guarantee or warranty of the product by the U.S. Dept. of Agriculture and does not imply its approval to the exclusion of other products or vendors that also may be suitable.
Russo and Perkins-Veazie, 1992). Soils in the region can be variable in depth and are underlaid with a clay hardpan. It is not clear how variability in depth affects bean production in the region.

Cultural methods can affect yield of a crop. Devising a system to produce beans that provides an acceptable return and reduces impact on the environment is important. Advantages of specific tillage systems depend on microclimate, soil characteristics, cropping systems, and management goals (Robertson et al., 1982).

Although there is little disease and insect pressure on beans in southeastern Oklahoma, it is important that weeds be controlled. Reduced-till management uses herbicides to control weeds. Xu and Pierce (1998) found that studies relating the tillage system to dry bean yield are limited, and they found that no-till management either had no effect on, or reduced, yields of dry beans. There have been few studies where effects of tillage and soil characteristics have been evaluated on commercial production-size fields. This project was undertaken to 